\title{
THE ACTIVITIES OF THE MINISTRY OF THE IMPERIAL COURT REGARDING CREATION OF THE WATER-PIPE SYSTEM OF THE GATCHINA TOWN UNDER ALEXANDER III
}

\author{
Andrey A. Efimov \\ Saint Petersburg Institute of History, Russian Academy of Sciences, Saint Petersburg, Russian Federation
}

\begin{abstract}
The paper deals with one of the most important issues in governing of the so-called "palace towns" ("dvortsovye goroda") by the Ministry of the Imperial Court. It scrutinizes the creation of the water supply system in Gatchina, the main country residence of Alexander III. The author claims this circumstance as one of the motives for the planning of future pipeline construction works. The special attention is paid to unbiased causes such as drying of wells in the town centre after sewerage laying and getting to the limit of the local water-supply system existing in the imperial residence. In his research on the preparatory process, the author especially mentions that Gatchina town manager M.M. Anichkov and town architect N.V. Dmitriev struggled to get maximum information concerning future consumers, relied on the practice of other Russian localities, and asked specialists for advice. Such forethought, however, didn't secure from complications during realization of the project. The author notes that $\mathrm{K}$. Ziegel, who got the contract for construction of the water-supply system in Gatchina, proved himself to be incapable of both timely delivery of pipes, equipment and other materials and of compliance with construction works' deadlines. The paper claims this situation to be the result of the policy when the contract was granted to a contractor suggesting the lowest price. However, the author especially outlines that creation of the water pipeline made it possible for the Court Department to become water supplier, and for town dwellers to get this communal service. The provisions of connection, maintenance and payment are under consideration in the paper's final part. The conditions of connection to the town's water pipeline are considered on the basis of archival documents.

Key words: Gatchina, Alexander III, Ministry of the Imperial Court, water-pipe system, N.V. Dmitriev, M.M. Anichkov, K. Ziegel.

Citation. Efimov A.A. The Activities of the Ministry of the Imperial Court Regarding Creation of the WaterPipe System of the Gatchina Town Under Alexander III. Vestnik Volgogradskogo gosudarstvennogo universiteta. Seriya 4, Istoriya. Regionovedenie. Mezhdunarodnye otnosheniya [Science Journal of Volgograd State University. History. Area Studies. International Relations], 2018, vol. 23, no. 4, pp. 62-74. (in Russian). DOI: https://doi.org/ 10.15688/jvolsu4.2018.4.7
\end{abstract}

\section{ДЕЯТЕЛЬНОСТЬ МИНИСТЕРСТВА ИМПЕРАТОРСКОГО ДВОРА ПО СОЗДАНИЮ СИСТЕМЫ ГАТЧИНСКОГО ГОРОДСКОГО ВОДОПРОВОДА ПРИ АЛЕКСАНДРЕ III}

\author{
Андрей Александрович Ефимов \\ Санкт-Петербургский институт истории РАН, г. Санкт-Петербург, Российская Федерация
}

Аннотация. Статья посвящена изучению одного из важнейших направлений деятельности Министер-
ства императорского двора по управлению дворцовыми городами, которым, несомненно, являлось их ком-
мунальное благоустройство и, в частности, создание системы централизованного водоснабжения. Автор
исследует историю создания Гатчинского общегородского водопровода, начало которому было положено в 
годы правления Александра III, выбравшего этот населенный пункт своей основной загородной резиденцией. Последнее обстоятельство, как отмечается в статье, косвенно являлось одним из побудительных мотивов к началу проектировочных работ. Не оставлены без внимания и объективные причины, которыми являлись пересыхание колодцев в центре города после прокладки канализации и достижение предельной нагрузки на действовавшую в императорской резиденции систему локального водопровода. Изучая ход подготовительных работ, автор особо отмечает, что руководивший Гатчиной М.М. Аничков и городской архитектор Н.В. Дмитриев старались собрать максимум сведений о потребностях потенциальных потребителей, учитывали опыт других населенных пунктов Российской империи, в которых водопровод уже был, и привлекали для консультаций специалистов-практиков. Однако подобная предусмотрительность не уберегла от осложнений при реализации проекта, когда получивший подряд К. Зигель оказался не способен ни подготовить вовремя необходимое количество труб, специальных устройств и других материалов, ни выдержать сроков производства работ. Основной причиной этого, по мнению автора, был принятый в министерстве порядок, по которому победителем тендера на производство работ становился тот, кто предложит наименьшую цену. Тем не менее в завершающей части статьи автор особо отмечает тот факт, что реализация основного проекта, в который изначально закладывалась возможность расширения трубопроводной сети, позволила Придворному ведомству на коммерческой основе стать поставщиком услуг водоснабжения для частных предпринимателей и простых жителей Гатчины. На основе архивных документов подробно рассматриваются сами условия подключения к городскому водопроводу.

Ключевые слова: Гатчина, Александр III, Министерство императорского двора, водопровод, Н.В. Дмитриев, М.М. Аничков, К. Зигель.

Цитирование. Ефимов А. А. Деятельность Министерства императорского двора по созданию системы Гатчинского городского водопровода при Александре III // Вестник Волгоградского государственного университета. Серия 4, История. Регионоведение. Международные отношения. - 2018. - Т. 23, № 4. - С. 62-74. DOI: https://doi.org/10.15688/jvolsu4.2018.4.7

Введение. Одним из важнейших вопросов, стоявших перед Министерством императорского двора при управлении дворцовыми городами, являлось их коммунальное благоустройство, предусматривавшее в том числе прокладку сетей водопровода и канализации, организацию освещения. В существующих исследованиях работа Министерства императорского двора в этой области практически не рассматривается, а основное внимание обращается на императорские резиденции, а не на городские кварталы.

Методы, материалы. По касательной эти вопросы затрагиваются в книгах «Столетие города Гатчины», подготовленной С.В. Рождественским [12], «Гатчина: страницы истории», составленной Т.Ф. Родионовой [11], и «Гатчина. От прошлого к настоящему. История города и его жителей», написанной А.Ю. Гусаровым [1]. Также необходимо отметить, что история создания систем водопровода в дворцовых городах практически не освещена. Существует исследование Н.И. Фальковского по истории водоснабжения в России, опубликованное в 1947 г. [13], а также несколько книг, изданных при участии ГУП «Водоканал Санкт-Петер- бурга», содержащих отдельные сведения по истории развития системы водоснабжения в Санкт-Петербурге и его пригородах. Однако ни одно из этих изданий историю Гатчинского водопровода не затрагивает.

В свою очередь, данная статья направлена на сокращение имеющейся историографической лакуны в части освещения истории начального этапа создания Гатчинского городского водопровода. При этом в ходе исследования выявилось, что пробелы имеются и в источниковой базе. Как единый комплекс существуют лишь документы Министерства императорского двора, тогда как в архивных делах компаний и организаций, работавших в области прокладки инженерных сетей, подавляющая часть бумаг не сохранилась ${ }^{1}$.

Анализ. Обращаясь непосредственно к истории развития Гатчинского водопровода, в первую очередь стоит отметить, что к середине 1880-х гг. в Гатчине действовал местный водопровод, обеспечивавший: императорский дворец с прилегавшими к нему постройками; оранжереи; Электромашинное здание, производившее электрический ток для нужд резиденции; и Кирасирские казармы с конюш- 


\section{ОТЕЧЕСТВЕННАЯ ИСТОРИЯ}

нями. Организован он был следующим образом: из Серебряного озера посредством шестидюймовой трубы вода забиралась и закачивалась в два бака, находившиеся над дворцом и вмещавшие в себя до 6500 ведер (около 80 куб. м), откуда уже самотеком расходилась по потребителям. Действие этой системы обеспечивалось специальным насосом производительностью 3000 ведер в час (около 37 куб. м/ч), приводившимся в действие паровой машиной мощностью в 15 л.с.

Основная часть жителей Гатчины, однако, не имела доступа к этому благу цивилизации и по состоянию на 1886 г. пользовалась водой или же из имевшихся при частных домах колодцев, или главным образом из Белого озера, находящегося в Дворцовом саду.

При этом прибывавшие водовозы причиняли неудобства жившей в Гатчинском дворце императорской семье. А после проведения работ по прокладке городской системы канализации колодцы на участках вдоль всего Большого пр. (пр. 25 Октября) и частично по Багговутской (Карла Маркса) и Мариинской (Киргетова) ул., Мариинскому пер. (ул. Радищева) и на территории Госпиталя пересохли, оставив эту часть города вовсе без воды. Последнее обстоятельство повлекло значительную интенсификацию поездок водовозов.

$\mathrm{B}$ «Пояснительной записке к смете на устройство водопровода с водоподъемными машинами для города Гатчино и Егерской слободы» архитектор Дмитриев отмечал, что на территории города и в прежние годы существовал недостаток воды, а с разрастанием города и ростом населения он стал еще более ощутим. Особенную опасность это представляло при возникновении пожаров, когда для обеспечения тушения пожарной команде приходилось тратить значительное время на поездки к водоемам.

Действовавшая на тот момент система водоснабжения находилась на пределе своих возможностей, поскольку связка паровая машина - насос работала по 22 часа в сутки. Такая продолжительная работа была обусловлена в первую очередь потребностями электрогенераторов, которые на тот момент потребляли до 50000 ведер (615 куб. м) воды в сутки и, по заявлению заведующего системой электроосвещения, для полноценного действия требовали 80000 ведер (984 куб. м) в сутки [8, л. 138-139 об.].

Таким образом, как для обеспечения потребностей горожан, так и для развития системы электроосвещения насущной необходимостью стало создание системы централизованного водопровода.

Осознав это, заведующий Императорским Гатчинским дворцом и г. Гатчина подполковник М.М. Аничков в 1885 г. отдал распоряжение архитектору гражданскому инженеру Н.В. Дмитриеву составить проект прокладки сети водоснабжения.

Первичный план предусматривал строительство водонапорной башни в 7 сажен (15 м) высоты, которая обслуживалась бы уже действовавшей паровой машиной с насосом. Сеть водопровода должна была идти по следующим направлениям: к Сенной пл. с водоразборной будкой (см. рис. 1), к зданию Зимнего Госпиталя и к зданию Полиции. Кроме того, на улицах предполагалось установить шесть пожарных кранов. Все эти работы по предварительной смете, представленной Ф.К. Сан-Галли, должны были обойтись в 48663 рубля [8, л. 6-6 об.].

К осени 1886 г. проект значительно увеличился, и в него кроме всего вышеизложенного вошло следующее:

1. Проведение водопроводной магистральной трубы до Егерской слободы.

2. Установка водоразборной будки у Пильной.

3. Дополнительное водоснабжение Электромашинного здания.

4. Монтаж дополнительно еще шести пожарных кранов.

5. Прокладка сети труб ко всем зданиям Госпитального комплекса, как то Зимний и Летний госпиталя, Баня, Прачечная, аптека, кухня, заразное отделение, арестантское отделение и др.

6. Для накачивания воды поставить второй насос с паровым двигателем с прокладкой от Серебряного озера второй заборной трубы.

Кроме того, Н.В. Дмитриев отмечал, что при составлении в 1885 г. предположения, вероятно, не было сделано предварительной ни- 
А.А. Ефимов. Деятельность Министерства императорского двора по созданию Гатчинского водопровода

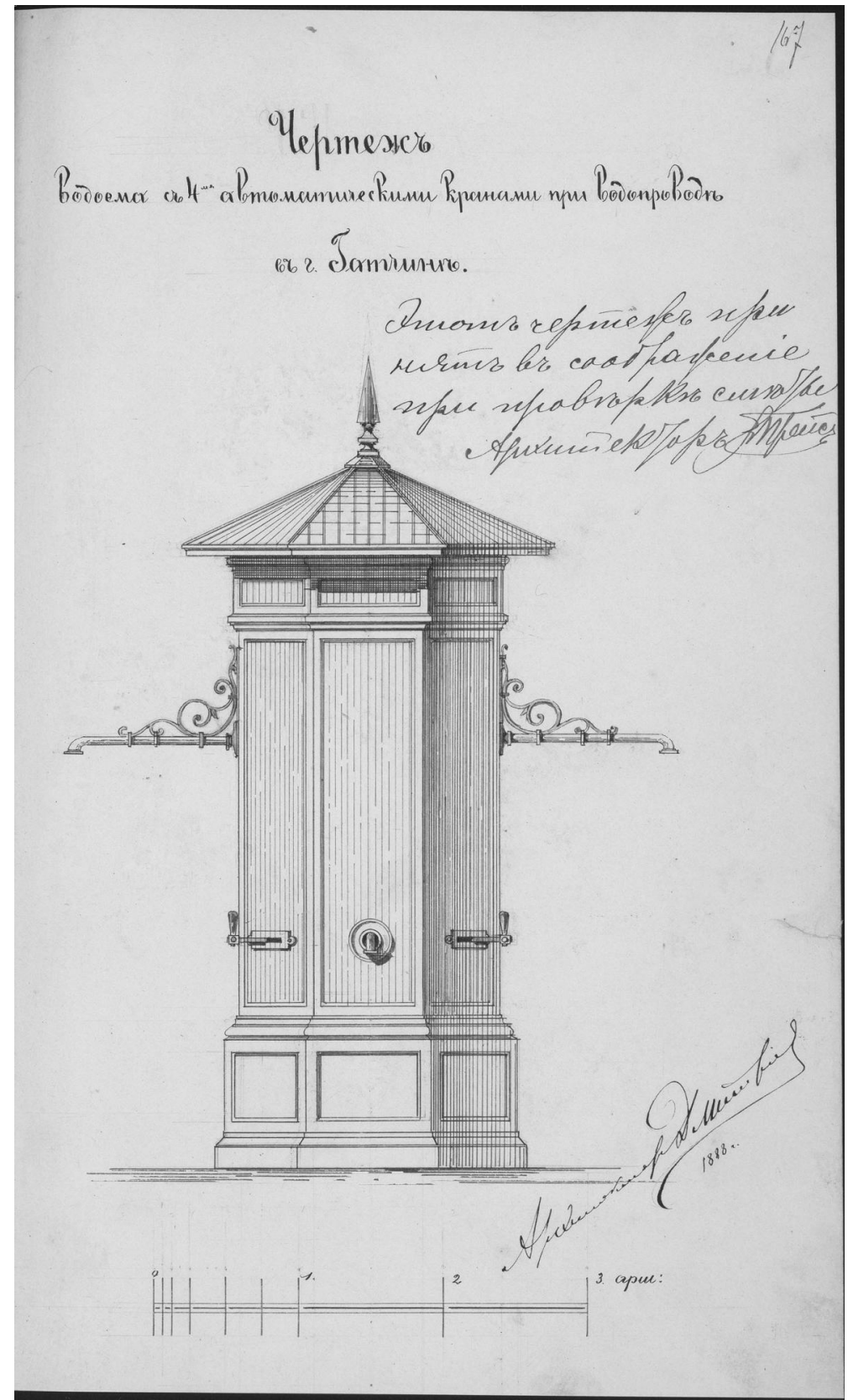

Рис. 1. Чертеж водоразборной колонки

Fig. 1. Scheme of a standpipe

велировки (см. рис. 2), а потому высота башни была определена ниже, чем следовало, а именно в 7 сажен (15 м), вместо необходимых 10 сажен (21,3 м).

Расширенный проект по приблизительному исчислению требовал на реализацию 94885 рублей.

Кроме того, под вопросом было потенциальное подключение к сети водопровода Николаевского сиротского института и Артиллерийских казарм. Для этого требовалось до- полнительное согласование, а само включение этих потребителей могло привести к увеличению общей сметы устройства водопровода, по представленному Н.В. Дмитриевым дополнительному расчету, до 118865 рублей $[8$, л. $6-6$ об.].

При подготовке проектно-сметной документации по подряду на прокладку общегородского водопровода в Гатчине руководивший городской администрацией полковник М.М. Аничков обратился к заведующему 


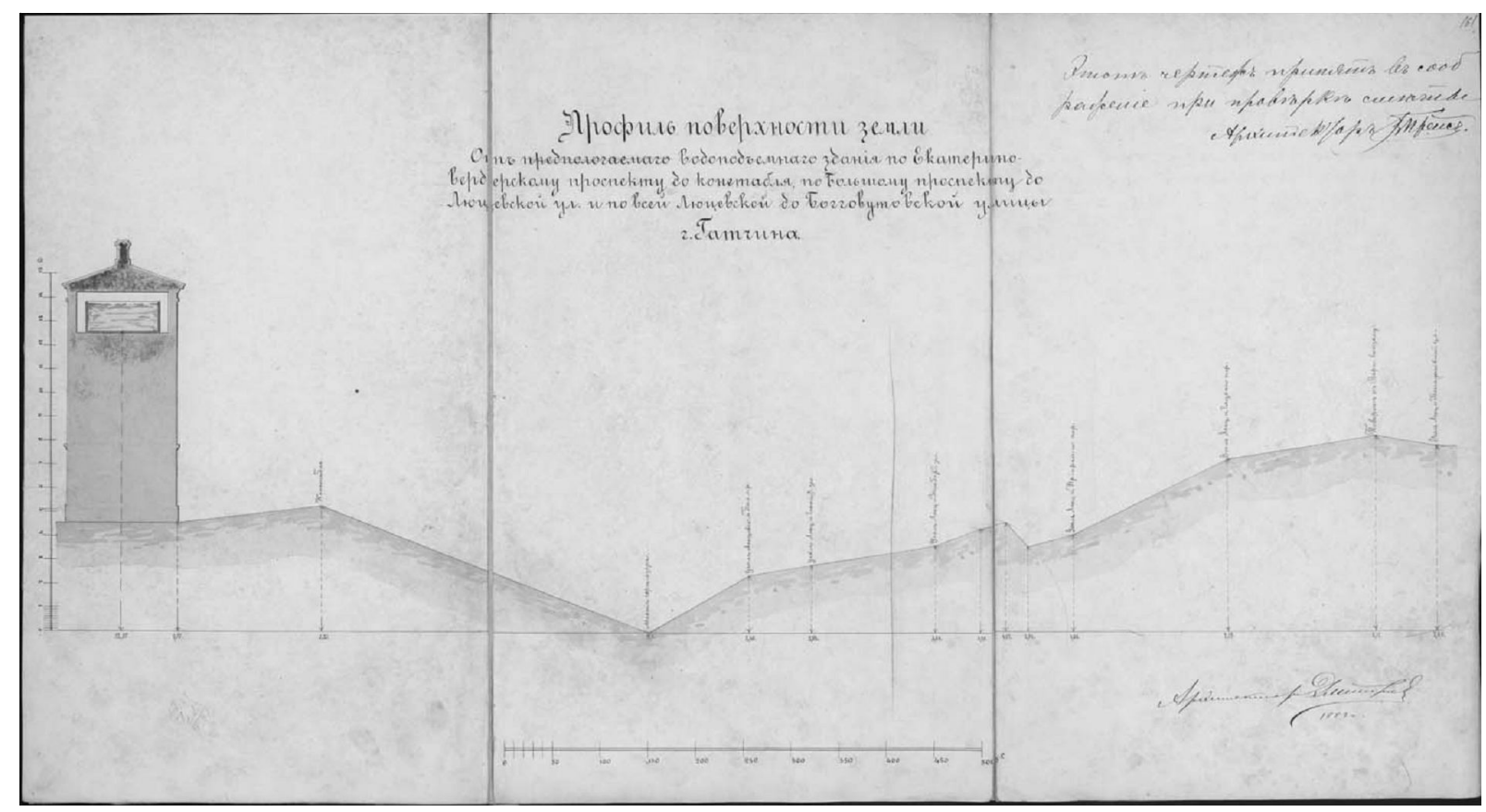

Рис. 2. Нивелировка трассы Гатчинского водопровода

Fig. 2. Levelling of track of the Gatchina water pipeline

императорскими Царскосельскими дворцами и г. Царское Село с просьбой прислать для сведения копии с подробной сметы и контрактов на водопроводные работы по Царскому Селу. Эти документы были получены в середине ноября 1887 г. и включали в себя в том числе проект и сметы инженерно-строительных работ [8, л. 34-73].

В ходе работы по подготовке к проведению торгов на прокладку водопровода M.M. Аничков также учитывал чужой опыт. При составлении сметных расчетов он счел нужным и полезным связаться с представителями действовавших в этой области компаний, обратившись в начале декабря 1887 г. к заводчикам О.Е. Крелю, руководившему Санкт-Петербургским металлическим заводом, К. Зигелю, Г.А. Лесснеру, Ф.К. Сан-Галли и инженеру-технологу, инженеру Общества Санкт-Петербургских водопроводов М.И. Алтухову [8, л. 78]. Представленные ими данные легли в основу документации для проведения торгов [8, л. 139 об.]. Затем уже в начале февраля 1888 г. заведующий Императорским Гатчинским дворцом и г. Гатчина связался с Калужской городской управой для получения копий с договоров, которые та заключала с М.И. Алтуховым на проведение воды в г. Калуге. Запрошенные бумаги были отправлены 10 февраля [8, л. 104, 105], и, по всей вероятности, стали одними из основных образцов для подготовки проекта подрядного контракта.

Предварительная «Смета на устройство водопровода с водоподъемными машинами для Гатчины и Егерской слободы» с приложением 23 чертежей и пояснительной запиской была представлена архитектором Н.В. Дмитриевым М.М. Аничкову в конце января 1888 г., и вскоре препровождена в Контроль МИДв для проверки. Согласно сохранившимся документам, смета, представленная в начале 1888 г., предусматривала расходы на оплату приобретения материалов и проведения работ в размере около 126000 рублей. Однако возвращенная в апреле того же года после проверки в Техническом отделе Контроля МИДв смета первоначально составляла около 128250 руб., а после проверки незначительно сократилась до 127750 рублей [8, л. 79-80, 97 об., 101, 121-122, 136 об.]. Подобное расхождение свидетельствует о вероятном составлении зимой - весной 1888 г. второй редакции документа с несколько увеличенными цифрами расходов, также представленной в Контроль МИДв. При этом в «Пояснительной записке к смете на устройство водопровода с водоподъемными ма- 
шинами для города Гатчино и Егерской слободы» фигурирует начальная цифра около 126000 рублей [8, л. 139 об.].

Окончательный проект создания системы водопровода в Гатчине предусматривал следующую схему прокладки трубопроводов:

1. Вода забиралась восьмидюймовой трубой из Серебряного озера и посредством насосов подавалась в баки, установленные в водоподъемной башне.

2. Первая ветка должна была пойти по Екатеринведерскому (Красноармейскому) пр. по направлению к Егерской слободе до площадки, находившейся у пруда близ Черных ворот, где устанавливался автоматический водоем (водоразборная колонка), а у дороги в Егерскую слободу монтировался тройник, от которого можно было бы впоследствии провести воду по всей слободе.

3. Вторая нитка шла по Екатеринведерскому (Красноармейскому) пр. через пл. Коннетабль по Большому пр. (пр. 25 Октября) до угла Люцевской ул. (ул. Чкалова), а от Люцевской ул. (ул. Чкалова) до Зимнего госпиталя с разводкой труб по его территории. Затем водопровод должен был пройти от угла Люцевской ул. (ул. Чкалова) и Большого пр. (пр. 25 Октября) до угла Госпитальной (Красной) ул. с последующим выходом на площадь у здания Полиции, с установкой на ней автоматического водоразборного водоема и прокладкой отдельных труб к зданию Полиции, к дому № 16 по Госпитальной (Красной) ул. и к дому № 2 на углу Елизаветинской ул. (ул. Достоевского) и Бомбардирской ул. (ул. Горького).

В результате вода была бы подведена ко всем домам Дворцового управления, а для нужд простых горожан планировалось установить два автоматических водоема с тремя кранами для водовозных бочек и одним краном для ведер.

Помимо этого, в разных местах должны были находиться пять стендеров, тридцать пожарных кранов и тридцать поливных тумб [8, л. 76, 138-139].

Для обеспечения функционирования всей этой системы предполагалось установить две новые паровые машины мощностью в 40 л.с. каждая ${ }^{2}$ и дополнительно смонтировать насос на 8000 ведер $(98,4$ куб. м) воды в час, а также возвести водонапорную башню высотой в 10 саженей $(21,3$ м) (см. рис. 3). В ней монтировались три бака, два на высоте 7,84 сажен $(16,7 \text { м })^{3}$ и объемом по 7500 ведер (92,25 куб. м) для обслуживания потребностей города и один для дальнейшей подачи воды на территорию Егерской слободы и Пильной в 4500 ведер $(55,35$ куб. м) на уровне 5,8 сажени (12 м). Кроме того, для накопления и распределения воды по территории города планировалось использовать баки, установленные на других зданиях: объемом 6500 ведер (80 куб. м) на Гатчинском дворце, в 4000 ведер (49,2 куб. м) над Кирасирскими казармами, на 3500 ведер (43 куб. м) над Госпитальными зданиями, а также емкости общим объемом 5000 ведер (61,5 куб. м), смонтированные над некоторыми другими домами Дворцового ведомства. С учетом всех перечисленных емкостей общий объем накопителей системы городского водопровода г. Гатчины должен был составить 38500 ведер (473,5 куб. м) [8, л. 75-75 об., 139-139 об.].

Из числа заводчиков и специалистов, к которым обращалось Гатчинское дворцовое управление в ходе подготовки документации к торгам на проведение водопровода, желание принять участие в тендере на обозначенных условиях изъявили: инженер М.И. Алтухов, предложивший выполнить работы за 105000 руб.; инженер К. Зигель, установивший свою цену на отметке 104500 руб., и Компания Санкт-Петербургского металлического завода, которая, предварительно подав особое заявление с измененным против общих условий перечнем работ, указала сумму 89000 рублей. В свою очередь Ф.К. Сан-Галли, предлагавший предварительно выполнить работы за 111338 руб., от тендера отказался, мотивировав это внесением в кондиции статей, не соответствовавших ранее представленной проектно-сметной документации как в части содержания, так и в части сумм и порядка перечисления выплат. Сами торги состоялись 1 июля 1888 г., а ценовые предложения участников остались на указанном уровне [8, л. 142, 184-188, 193-194].

Такие расценки не удовлетворили Гатчинское дворцовое управление, условия будущего контракта были скорректированы, а пе- 


\section{ОТЕЧЕСТВЕННАЯ ИСТОРИЯ}

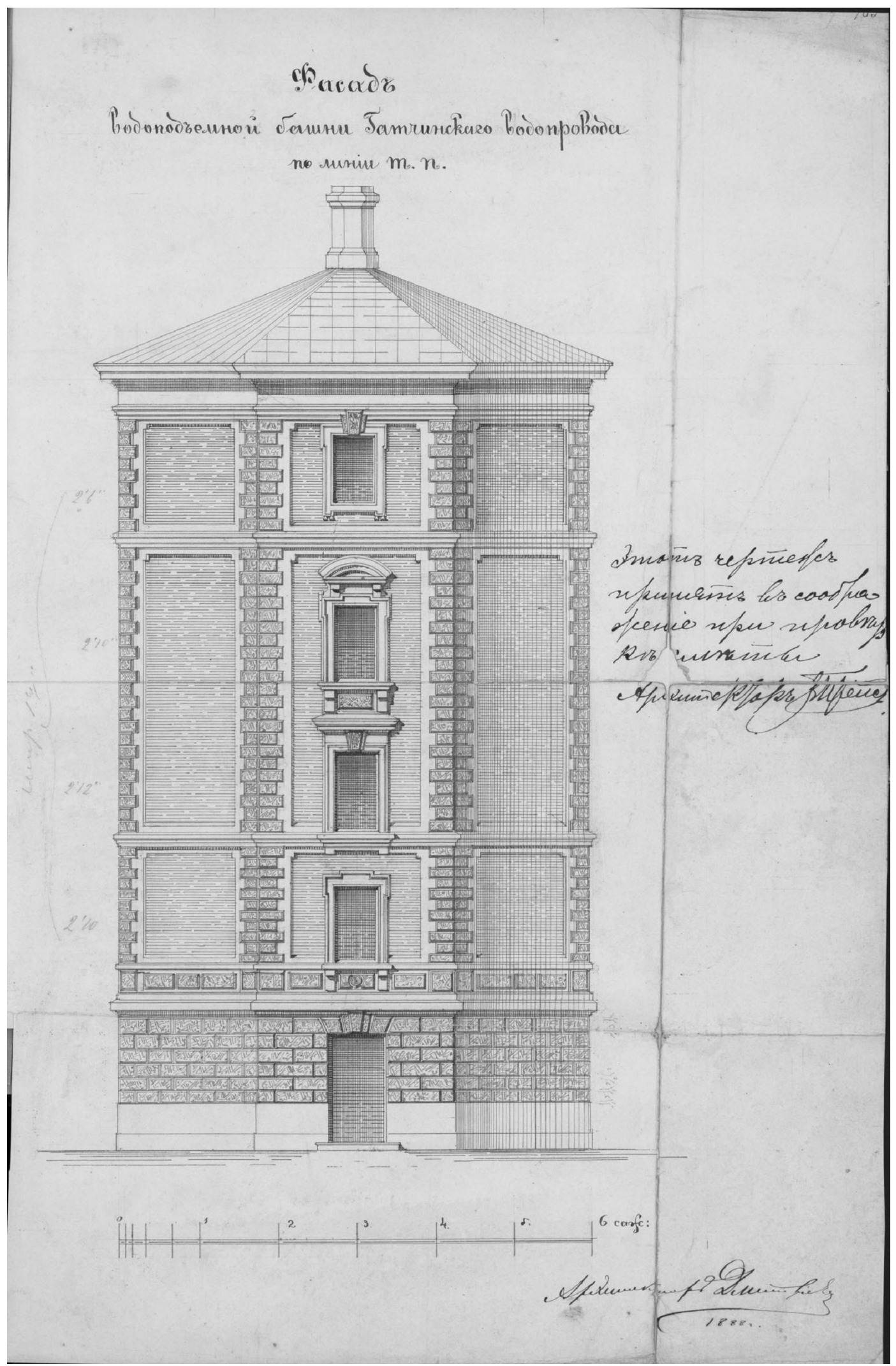

Рис. 3. Чертеж водоподъемной башни Гатчинского водопровода

Fig. 3. Scheme of water tower of the Gatchina pipeline 
реговоры с потенциальными подрядчиками продолжены. М.И. Алтухов принял предложенные условия контракта без всяких оговорок и предложил 86849 рублей. Ф.К. Сан-Галли согласился выполнить работы за 84134 руб. с уточнением вопросов финансирования, установив для себя приемлемой оплату по мере выполнения работ с получением задатка в половину сметной суммы под залог по схеме «рубль за рубль» и удержанием в качестве гарантийного обеспечения качества работ процентных бумаг вместо реальных денег. В свою очередь К. Зигель предложил две цены в зависимости от применяемого насоса: 1) с одной паровой машиной и насосом с передаточным механизмом за 76900 руб., или 2) с паровым насосом за 71900 рублей. Компания Санкт-Петербургского металлического завода, не успевая подготовить свое ценовое предложение, обратилась за трехдневной отсрочкой, однако это обращение осталось без внимания.

Повторный тендер прошел 5 июля 1888 г., где все участники сохранили неизменными свои последние предложения, а победителем стал К. Зигель, давший наименьшую цену в 76900 рублей [8, л. 196, 203-203 об., 211, 219, 220-221].

Согласование итогов торгов было завершено к 21 июля, когда управляющий Кабинетом Е.И.В. статс-секретарь Н. Петров направил соответствующее письмо заведующему императорским Гатчинским дворцом и г. Гатчина, в котором также уведомлял об утверждении представленного в начале месяца проекта контракта. Соглашение Гатчинского дворцового управления с К. Зигелем было заключено 4 августа 1888 года [8, л. 230230 об., 240].

Работы по прокладке труб были начаты еще в конце июля; однако у подрядчика сразу же возникли технические трудности. К. Зигель 26 июля направил в Гатчинское дворцовое управление письмо, в котором ссылался на сложность изготовления моделей для отливки восьмидюймовых труб с обозначенными в подписанных им кондициях весовыми параметрами, значительно превышавшими базовые величины. Он просил разрешить ему впредь до подготовки необходимых моделей использовать более легкие трубы, соглаша- ясь в свою очередь на вычет из будущего вознаграждения за работы и обещая надежную службу проложенных труб [8, л. 228-228 об.]. Это изменение было согласовано, а 1 августа была проведена успешная проверка повышенным давлением в 180 psi (около 12,5 атм) первого участка в 81 пог. саж. (172,5 м) труб. от Серебряного пруда до Большой дороги; а к началу сентября сеть водопровода была протянута к Электромашинному зданию, частично охватила Большой пр. (пр. 25 Октября), прошла по Люцевской ул. (ул. Чкалова) через Госпитальную (Красную) ул. (с поперечным ответвлением на перекрестке) и Приоратский пер. (ул. Леонова) до дома № 8; а также по Екатеринведерскому (Красноармейскому) пр. от пересечения дорог мимо дворца к Балтийской ж.д. [8, л. 239, 251, 256, 260, 263, 264, 269]. По Екатеринведерскому (Красноармейскому) пр., по Большому пр. (пр. 25 Октября) и Люцевской ул. (ул. Чкалова) до Госпитальной (Красной) ул. и к Электромашинному зданию шли восьмидюймовые трубы, от Госпитальной (Красной) ул. до Приоратского пер. (ул. Леонова) - шестидюймовые, а от Приоратского пер. (ул. Леонова) - четырехдюймовые. Подобное изменение диаметра стоит связывать как с необходимостью поддерживать напор в системе, так и с уменьшением к концу линии числа потенциальных потребителей.

За следующий месяц работы продвинулись по Большому пр. в двух направлениях: от левого берега Черного озера через само озеро, канаву к Карпичному пруду к обелиску Коннетабль с поворотом на Екатеринведерский (Красноармейский) пр. через каменный мост были проложены восьмидюймовые трубы, а от Люцевской ул. (ул. Чкалова) до Госпитального пер. шла шестидюймовая труба. Вдоль Люцевской ул. (ул. Чкалова) уложили четырехдюймовые трубы на участке от дома № 8 (Кузнецовой) по направлению к Варшавскому вокзалу мимо дома № 9 (Пономарева) до угла Багговутской ул. (ул. Карла Маркса). Такого же диаметра водопровод был проведен от угла Большого пр. (пр. 25 Октября) по Госпитальному пер. до Зимнего Госпиталя и по Госпитальной (Красной) ул. от угла Люцевской ул. (ул. Чкалова) до колодца с запорным краном, от которого отходила трехдюймовая труба к водоему на Торговой площади. Трех- 
дюймовые трубы прошли от Мариинской (Рaдищева) ул. (площадки у Зимнего Госпиталя) около Дворцового здания № 1 до выезда на Багговутскую ул. (ул. Карла Маркса) у ворот близ Летнего Госпиталя; в роще между зданиями Зимнего Госпиталя и Богадельни мимо деревянного флигеля, занимаемого конторой Госпиталя, к Летнему Госпиталю; а также по Госпитальной (Красной) ул. от дома Будунова (Соборная ул., д. 4/9) [8, л. 271, 272, 276, 279, 281, 283, 286, 288, 290, 293].

Такие темпы работ не устроили руководство Гатчины; и еще 22 сентября К. Зигелю было указано, что к 1 октября по условиям контракта он должен был не только проложить все трубы, но и вернуть на место старую паровую машину с котлом и насосом и установить два водоема (водоразборных колонки). При этом, по наблюдениям чиновников Придворного ведомства, работы продвигались с отставанием от графика, и особое беспокойство вызывала задержка с прокладкой водозаборных труб к Серебряному пруду, не позволявшая вернуть этой прилегавшей к дворцу территории первоначальный вид. Причина же отставания виделась в недостаточном числе задействованных рабочих. Ликвидировать это отставание за полторы недели так и не удалось, и 3 октября архитектор Н.В. Дмитриев доносил М.М. Аничкову, что к указанному в договоре сроку подрядчиком были лишь проложены все трубы, тогда как остальные работы лишь только начались. Срыв сроков исполнения контрактных обязательств вынудил заведующего Императорским Гатчинским дворцом и г. Гатчина пригрозить К. Зигелю штрафом в 50 руб. за каждый день просрочки, начиная с 1 октября 1888 года [8, л. 273, 294-295 об.].

Однако К. Зигель не принял этого наказания, и в ответном письме сослался на непредвиденные и не зависевшие от него обстоятельства, как то необходимость переделки старого насоса ввиду установки в старый колодец нового, задержка в окончании строительных работ в кочегарном здании и позднее предоставление параметров канализационных колодцев у водоемов. Обращение принесло свои плоды, и 6 октября подрядчик получил отсрочку до 15 октября. К указанной дате также успеть не получалось, поскольку уста- новке старого насоса мешали строительные работы, а установке водоема у Егерской слободы препятствовало разбитие при перевозке по железной дороге чугунного постамента, взамен которого изготовлялся новый. Продолжавшиеся задержки с выполнением работ лишь укрепили негативное мнение М.М. Аничкова о деловых качествах подрядчика. Заведующий Императорским Гатчинским дворцом и г. Гатчина писал К. Зигелю: «Теперь я вполне убедился, что медленное исполнением вами мелких работ происходит не от препятствий по доставке того или другого материала, а прямо от неправильного и даже небрежного в известных случаях, исполнения срочных работ, вами принятых на себя» [8, л. 296-297, 299-301].

Однако в некоторых случаях перенос даты выполнения отдельных пунктов контракта происходил по прямой инициативе Гатчинского дворцового управления. Так, крайний срок установки баков для воды в водонапорной башне был перенесен с 5 декабря 1888 г. на январь 1889 г., тогда как срок пуска всей системы водопровода отныне был установлен на 5 марта 1889 года. Однако это стало единственным исключением, и установка новых насоса, паровой машины и котла должна была завершиться по указанию М.М. Аничкова к контрактному сроку 5 декабря 1888 года. При этом приемка всех уже выполненных работ, на скорейшем проведении которой в письме-отношении от 28 октября настаивал К. Зигель, в соответствии с договором могла состояться не ранее завершения всех прописанных в нем работ [8, л. 302-302 об., 304-305].

По состоянию на середину декабря 1888 г. подрядчиком по предоставленному им перечню было выполнено работ на общую сумму 57324 руб. 50 коп., из которых к тому моменту было выплачено 31250 рублей. Архитектор Н.В. Дмитриев, контролировавший ход прокладки водопровода, и техник Контроля МИДв согласовали выплату еще 11000 руб. [8, л. 311], тогда как оставшаяся сумма в 15000 руб. или удерживалась как гарантийное обязательство, или была предъявлена безосновательно за незавершенные работы.

К началу 1889 г. работа водопровода обеспечивалась водокачальной машиной, состоявшей из кочегарного и машинного отде- 
лений. Она была установлена в каменном доме № 3 по Екатеринведерскому (Красноармейскому) пр., к которому примыкала водонапорная башня. Последняя представляла собой каменное сооружение, стоявшее на уложенном на глинистый грунт ростверке, с железными балками и бетонными перекрытиями [7, л. 25 об.-27б, 53 об.-55].

Прокладка городского водопровода продолжалась фирмой К. Зигеля и в дальнейшем. Так, в 1890 г. на эти цели было израсходовано 12021 руб. [5, л. I], а за 1891 г. трубопровод был проведен по Мариинской ул. (ул. Киргетова), Константиновской ул. (ул. Радищева) и по Глухому пер. (ул. Лейтенанта Шмидта), а в Дворцовом саду действовавшая система была расширена [9, л. 1а-2 об.]. На следующий год с выделением 4560 руб. [3, л. 109] водопровод продвинулся еще на 105 саженей $(223,65$ м) по Глухому пер. (ул. Лейтенанта Шмидта), вдоль Николаевской ул. (ул. Урицкого) проложили 276,66 сажени (589,3 м) труб, расширена была также система водопровода близ Гатчинского дворца [10, л. 1-2]. В 1894 г. на продолжение устройства городского водопровода Гатчинским дворцовым правлением было израсходовано 13280 рублей [6, л. 23 об.24]. Одновременно с прокладкой труб монтировалась запорная арматура для подключения пожарных и поливных рукавов, ставились отводы для потребителей.

Создание сети водопровода, начало функционирования которого Т.Ф. Родионова относит к 1890 г. [9, с. 80-81], открыло возможность для рядовых домовладельцев Гатчины воспользоваться этим благом цивилизации. Специально для урегулирования этого вопроса городское руководство разработало особый нормативный акт, регламентировавший порядок и стоимость подключения потребителей, текущего обслуживания сетей и оплаты предоставляемых услуг. Первая редакция этого документа, подготовленная в 1890 г. как временная, именовалась «Проект правил о пользовании водою из Гатчинского городского водопровода» и была подписана заведующим Императорским Гатчинским дворцом и г. Гатчина гвардии полковником М.М. Аничковым [2, л. 98]. В преамбуле документа был четко очерчен круг потенциальных клиентов новой услуги, ограниченный обитателями тех улиц, по которым была проложена магистральная труба [2, л. 97]. Остальным же следовало дожидаться дальнейшего развития общегородской сети.

Желающие провести водопровод в свои владения должны были обратиться с соответствующим заявлением в Гатчинское дворцовое управление, оплатив положенный гербовый сбор. В обращении следовало указать площадь участка, количество устройств-потребителей [ватерклозетов, ванн и «прачечных» (приспособлений для механизированной стирки)], поголовье крупного рогатого скота и лошадей, количество и характер торговых точек. Впоследствии потребители имели право изменять эти параметры, уведомив о том городскую администрацию [2, л. 97, 98].

Стоимость непосредственно подключения к магистральной трубе составляла 60 руб., которые шли на установку колодца с запорным краном и отводом, а сверх того при необходимости доведения трубы до границы участка по 7 руб. за прокладку одной погонной сажени (2,13 м). Указанные работы производились Дворцовым правлением и сдавались в ведение последнего. Однако поддержание этих объектов в исправности возлагалось на потребителей, и в случае какого-либо повреждения городские власти имели право потребовать замены сломанных элементов, а в крайнем случае принудительно отключить подачу воды, выполнить необходимый ремонт, а счет за него предъявить получателю услуги для оплаты и лишь после внесения денег открыть кран. Прокладка труб на самом участке и в зданиях целиком и полностью производилась домовладельцем, получавшим предварительно разрешительные документы [2, л. 97-97 об.].

«Проектом правил...» устанавливался следующий порядок внесения абонентской платы: деньги вносились вперед за каждое полугодие, начиная с дня открытия запорного крана после проверки служащим Дворцового управления проведенных потребителем водопроводных работ. Получение средств подтверждалось выдачей квитанции, в которой указывался срок оплаты и перечислялись предметы - потребители воды. Тарифы были следующими: за трактирное заведение или гостиницу по 30 руб., прачеч- 
ную по 5 руб. и с головы лошади или рогатого скота по 1 руб., за ватерклозет по 2 руб. и за ванну по 4 рубля. Особый тариф был установлен для общественных бань, владельцы которых должны были предварительно оплатить установку водомера (счетчика) и затем отчисляли по 7 коп. за сто ведер (1,23 куб. м). Просрочка выплаты закономерно вела к отключению услуги, и для возобновления подачи воды следовало внести всю полугодовую плату, считая со дня окончания предыдущего авансового платежа. При этом в случае приостановки предоставления услуги по вине Дворцового управления, например, в связи с ремонтом магистральной трубы, перерасчета платы не производилось, а воду потребители должны были самостоятельно доставлять от общих водоразборных колонок [2, л. 97 об.-98].

Как и отмечалось в завершении текста «Проекта правил о пользовании водою из Гатчинского городского водопровода», этот документ являлся временным. В 1892 г. была подготовлена его новая редакция, и 29 июня 1892 г. управляющий Кабинетом статс-секретарь Н. Петров утвердил «Правила для пользования водой из Гатчинского водопровода», которые отныне применялись ко всем потребителям, в том числе и государственным [4, л. 127, 128 об.].

Изменениям в той или иной степени подверглись все положения прежде действовавших правил. Наиболее кардинальным из них стало предоставление возможности альтернативной системы оплаты: наравне с прежде действовавшей авансовой «оптовой» платой вводилась оплата по «водомеру» (счетчику). При этом еще в самом начале при подаче заявления на подключение следовало сделать выбор одного из этих вариантов.

Стоимость работ по подключению незначительно выросла, отныне за устройство колодца со створным краном и отводом трехили четырехдюймовой трубы взималось 65 руб., а за прокладку отвода от магистрали диаметром 1,5 дюйма по-прежнему брали 7 руб. за погонную сажень (2,13 м). Разводка труб по участку и внутри зданий отныне хотя и производилась так же за счет потребителя, но велась под надзором техника Дворцового управления [4, л. 128].
Корректировке подверглись и тарифы абонентской платы: вводилась плата с площади жилых помещений в размере 15 коп. за квадратную сажень (4,55 кв. м) без учета лестниц; за каждый ватерклозет и ванну по 1 руб. 70 коп.; за каждую голову скота по 1 руб., за обрабатываемые огороды по 1 коп. с квадратной сажени (4,55 кв. м) занятого ими пространства; за бани по 2 руб. 50 коп. с квадратной сажени $(4,55$ кв. м) внутреннего пространства, считая раздевалку. Отдельная тарифная сетка действовала для постоялых дворов, трактиров и гостиниц: взималось по 50 коп. за квадратную сажень (4,55 кв. м) жилого помещения, а отдельные номера гостиниц приравнивались к обычному жилью с платой в 15 коп. с квадратной сажени (4,55 кв. м), а кроме того, за извозчичьи и постоялые дворы по 3 коп. за квадратную сажень (4,55 кв. м) этих дворов. Оплата по счетчику осуществлялась по единому тарифу в 5 коп. за 100 ведер (1,23 куб. м). Для водоснабжения производственных помещений (фабрик, мастерских, прачечных и др.) следовало заключить особое соглашение с Дворцовым управлением или установить отдельный счетчик. Абонентская плата по-прежнему вносилась за полгода вперед, а показания водомера оплачивались ежемесячно. Также неизменным сохранилось правило об отсутствии перерасчета за перерывы в водоснабжении при ремонтных работах и в случае сокращения объемов потребления [4, л. $128-128$ об.].

По состоянию на 1891 г. к городскому водопроводу было подключено 49 потребителей, которые выплачивали в среднем от 20 до 60 руб., а полярными цифрами были с одной стороны 6 руб., а с другой 1000 руб., которые вносил один из потребителей. Кроме того, по одному пользователю платили 140 руб., 300 руб., 550 руб. и 650 рублей [3, л. 14].

Результаты. В завершение стоит еще раз отметить основные моменты, связанные с появлением и этапом первичного развития Гатчинского городского водопровода.

Создание этой системы оказалось продиктовано как объективными факторами, такими как разрастание населенного пункта и истощение доступных способов обеспечения населения питьевой водой, так и, вероятно, выраженным членами императорской семьи 
недовольством неупорядоченным посещением дворцового сада повозками-водовозами. Большое внимание было уделено этапу планирования сети будущего водопровода, сопровождавшемуся опросом потенциальных потребителей и сбором информации о ранее созданных системах водопровода, а также бюрократическому оформлению документации. Однако политика выбора на торгах предложения с наименьшей ценой вылилась в осложнения при проведении работ, проявившиеся, в частности, в срыве сроков и корректировке технических параметров системы.

Задуманный первоначально для обеспечения потребностей в первую очередь дворцовых и казенных зданий, Гатчинский городской водопровод практически сразу стал доступен и рядовым горожанам. Причем для организации подключения и водоснабжения новых потребителей чиновниками Придворного ведомства были разработаны специальные правила. Такой поворот к потребностям обывателей также внес свой вклад в обеспечение дальнейшего развития этой коммунальной системы.

К столетию Гатчины система централизованного водоснабжения охватила около 1/3 территории города [1, с. 266]. Таким образом, можно считать, что царствование Александра III стало периодом формирования скелета одной из основополагающих коммунальных систем, характерных для современного города, развитие которой продолжалось в прошлом и продолжается до сих пор.

\section{ПРИМЕЧАНИЯ}

\footnotetext{
1 Применительно к истории создания системы водопровода в Гатчине были просмотрены хранящиеся в Центральном государственном историческом архиве Санкт-Петербурга материалы фондов Чугунолитейного и механического заводов «Сан-Галли» (Ф. 1254) и Акционерного общества «Компания Петроградского металлического завода» (Ф. 1357). Однако переписка с Придворным ведомством по вопросу прокладки Гатчинского водопровода представлена в фонде завода Ф.К. СанГалли только кондициями с несколькими техническими карандашными пометками, а в документах Металлического завода отсутствует вовсе.

2 Установка паровых машин такой мощности, по мнению Н.В. Дмитриева, позволила бы в бу-
}

дущем обеспечивать и функционирование городской системы электрического освещения [8, л. 139].

3 Эта отметка уровня днища баков была получена методом суммирования высшей точки нивелировки города в 3,62 сажени (7,7 м), наивысшего уровня уже установленных баков, также составлявшего 3,62 сажени (7,7 м), и установленного архитектором запаса «на трение» в размере 0,6 сажени (1,3 м) [8, л. 139].

\section{СПИСОК ЛИТЕРАТУРЫ}

1. Гусаров, А. Ю. Гатчина. От прошлого к настоящему. История города и его жителей / А. Ю. Гусаров. - СПб. : Русская тройка-СПб, 2012. $-348 \mathrm{c}$.

2. О составлении финансовых смет // Российский государственный исторический архив (РГИА). - Ф. 491. - Оп. 3. - Д. 334.

3. О составлении финансовых смет // РГИА. Ф. 491. - Оп. 3. - Д. 378.

4. О составлении финансовых смет // РГИА. Ф. 491. - Оп. 3. - Д. 398.

5. Отчет остроительных работах, произведенных по Гатчинскому дворцовому правлению // РГИА. Ф. 491.-Оп. 6. - Д. 104.

6. Отчет о строительных работах по Гатчинскому дворцовому правлению // РГИА. - Ф. 491. Оп. 6. - Д. 108.

7. Отчет о строительных работах, произведенных по Гатчинскому дворцовому управлению за 1888 г. // РГИА. - Ф. 491. - Оп. 6. - Д. 99.

8. По вопросу водоснабжения города Гатчино и об устройстве чугунно-трубного водопровода инженером Зигелем // РГИА. - Ф. 491. - Оп. 3. - Д. 239.

9. По устройству городского водопровода // РГИА. - Ф. 491. - Оп. 3. - Д. 382.

10. По устройству городского водопровода // РГИА. - Ф. 491. - Оп. 3. - Д. 415.

11. Родионова, Т. Ф. Гатчина: страницы истории / Т. Ф. Родионова. - М. ; СПб. : Герда, 2001 .$207 \mathrm{c}$.

12. Рождественский, С. В. Столетие города Гатчины. 1796-1896 / С. В. Рождественский. - Гатчина : Гатчин. дворцовое упр., 1896. - Т. 1. - [8], III, 323, 94 с., 4 л. фронт.

13. Фальковский, Н. И. История водоснабжения в России / Н. И. Фальковский. - М. ; Л. : Изд-во м-ва коммунального хоз-ва РСФСР, 1947. - 307 с.

\section{REFERENCES}

1. Gusarov A.Yu. Gatchina. Ot proshlogo $k$ nastoyashchemu. Istoriya goroda i ego zhiteley 
[Gatchina. From Past to Present. The History of the Town and Its Inhabitants]. Saint Petersburg, Russkaya troika-SPb Publ., 2012.348 p.

2. O sostavlenii finansovykh smet [On Drawing Up a Budget]. Rossiyskiy gosudarstvennyy istoricheskiy arkhiv [Russian State Historical Archive], F. 491, Op. 3, D. 334.

3. O sostavlenii finansovykh smet [On Drawing Up a Budget]. Rossiyskiy gosudarstvennyy istoricheskiy arkhiv [Russian State Historical Archive], F. 491, Op. 3, D. 378.

4. O sostavlenii finansovykh smet [On Drawing Up a Budget]. Rossiyskiy gosudarstvennyy istoricheskiy arkhiv [Russian State Historical Archive], F. 491, Op. 3, D. 398.

5. Otchet o stroitelnykh rabotakh, proizvedennykh po Gatchinskomu dvortsovomu pravleniyu [Report about Construction Works Carried out by the Palace Directorate of Gatchina]. Rossiyskiy gosudarstvennyy istoricheskiy arkhiv [Russian State Historical Archive], F. 491, Op. 6, D. 104.

6. Otchet o stroitelnykh rabotakh po Gatchinskomu dvortsovomu pravleniiu [Report about Construction Works Carried out by the Palace Directorate of Gatchina]. Rossiyskiy gosudarstvennyy istoricheskiy arkhiv [Russian State Historical Archive], F. 491, Op. 6, D. 108.

7. Otchet o stroitelnykh rabotakh, proizvedennykh po Gatchinskomu dvortsovomu upravleniiu za 1888 g. [Report about Construction Works Carried out by the Palace Directorate of
Gatchina in 1888] Rossiyskiy gosudarstvennyy istoricheskiy arkhiv [Russian State Historical Archive], F. 491, Op. 6, D. 99.

8. Po voprosu vodosnabzheniya goroda Gatchino i ob ustroystve chugunno-trubnogo vodoprovoda inzhenerom Zigelem [On Water-Supply of the Town of Gatchina and Laying of Cast Iron Pipes for Water-Supply System by Engineer Ziegel]. Rossiyskiy gosudarstvennyy istoricheskiy arkhiv [Russian State Historical Archive], F. 491, Op. 3, D. 239.

9. Po ustroystvu gorodskogo vodoprovoda [On the Development of Urban Water-Supply System]. Rossiyskiy gosudarstvennyy istoricheskiy arkhiv [Russian State Historical Archive], F. 491, Op. 3, D. 382.

10. Po ustroystvu gorodskogo vodoprovoda [On the Development of Urban Water-Supply System]. Rossiyskiy gosudarstvennyy istoricheskiy arkhiv [Russian State Historical Archive], F. 491, Op. 3, D. 415.

11. Rodionova T.F. Gatchina: stranitsy istorii [Gatchina: the Pages of History]. Moscow, Saint Petersburg, Gerda Publ., 2001. 207 p.

12. Rozhdestvenskiy S.V. Stoletie goroda Gatchiny. 1796-1896 [The Centenary of the Town of Gatchina. 1796-1896]. Gatchina, Gatchin. dvortsovoe upr. Publ., 1896, vol. 1. 421 p.

13. Falkovskiy N.I. Istoriya vodosnabzheniya $v$ Rossii [The History of Water-Supply in Russia]. Moscow; Leningrad, Izdatelstvo ministerstva kommunalnogo khoziaistva RSFSR Publ., 1947.307 p.

\section{Information about the Author}

Andrey A. Efimov, Candidate of Sciences (History), Researcher, Saint Petersburg Institute of History, Russian Academy of Sciences, Petrozavodskaya St., 7, 197110 Saint Petersburg, Russian Federation, aaefimov5@gmail.com, https://orcid.org/0000-0001-9016-1091

\section{Информация об авторе}

Андрей Александрович Ефимов, кандидат исторических наук, научный сотрудник, СанктПетербургский институт истории РАН, Петрозаводская ул., 7, 197110 г. Санкт-Петербург, Российская Федерация, aaefimov5@gmail.com, https://orcid.org/0000-0001-9016-1091 